\title{
Study of the Causes and Magnitude of Wastage of Materials on Construction Sites in Jordan
}

\author{
Ghanim A. Bekr \\ College of Engineering, The Applied Science University, P.O. Box 166, Shafa Badran, Amman 11931, Jordan \\ Correspondence should be addressed to Ghanim A. Bekr; ghanimbekr@yahoo.com \\ Received 28 May 2014; Revised 17 September 2014; Accepted 1 October 2014; Published 28 October 2014 \\ Academic Editor: Martin Cyr \\ Copyright (C) 2014 Ghanim A. Bekr. This is an open access article distributed under the Creative Commons Attribution License, \\ which permits unrestricted use, distribution, and reproduction in any medium, provided the original work is properly cited.

\begin{abstract}
The research aims to study the causes and magnitude of wastage of construction materials on construction projects sites in Jordan. To achieve the research aim, the researcher had prepared a questionnaire form included questions about the causes of wastage and the estimated percentages of wastage of ten most popular kinds of materials used on construction sites in Jordan. Prior to the final formulation of the questionnaire form, a pilot survey was conducted. The form was revised in accordance with the feedback received. The number of causes adopted was 60 distributed on the six major categories. The form was distributed to 240 participants (clients, contractors, and consultants). The study revealed that the most important causes of wastage of materials on construction sites in Jordan are frequent design and client's changes; rework due to workers mistakes; poor contract documents; wrong and lack of storage of materials; poor strategy for waste minimization; shortage and lack of experience of skilled workers; poor site conditions; damage during transportation; theft and vandalism; and mistakes in quantity surveying and over allowance. In addition the study concluded that the percentage of wastage materials is accounted for by values between $15 \%$ and $21 \%$ on Jordanian construction sites.
\end{abstract}

\section{The Objective of the Research}

The objective of the research is to identify the major causes of material waste on construction sites in Jordan based on the opinion of contractors, consultants, and owners also to assess the quantities of wastage in main building materials used in the Jordanian construction sites and making comparison with the other countries.

\section{The Construction Industry in Jordan}

Jordan is considered one of the most stabled countries in the Middle East, attracting considerable amounts of investments from surrounding countries.

The construction sector has been one of the most active sectors of the Jordanian economy lately. Construction sector accounted for $4.4 \%$ of the Gross Domestic Product (GDP) on average over the period 2008-2010. The sector has grown at a Compound Annual Growth Rate (CAGR) of $13.7 \%$ during the same period. Credit to the construction sector has also expanded by a CAGR of $20.5 \%$, with the highest growth rates of $34.3 \%$ and $24.4 \%$ registered for 2009 and 2010, respectively [1].

Construction materials costs are going through a period of price increase for almost all variety of construction materials. In a study carried out by the Ministry of Housing and Reconstruction in Jordan [2], it is found that this increase for the period 2010 to 2012 is between $11.5 \%$ and $15.2 \%$. This will strongly support the necessity of carrying this research.

\section{Definition of Wastage of Material}

Many authors defined the term of wastage. Construction waste as defined by Ekanayake and Ofori [3] is any material apart from earth material which needs to be transported elsewhere to the construction sites or used within the construction site itself for the purpose of land filling, incineration, recycling, reusing, or composting rather than the intended specific purpose of the project due to material change excess, 
nonuse, or noncompliance with the specifications or being a byproduct of the construction process.

Building material wastage can also be defined as the difference between the value of materials delivered and accepted on site and those properly used as specified and accurately measured in the work after deducting the cost saving of substituted materials transferred elsewhere in which unnecessary cost and time may be increased by the material wastage [4].

Keal [5] further stressed that any substance or object that is not useful or will be not useful is waste and is subject of a number of conditions. Dania et al. [6] assert that construction and demolition waste is a complex waste stream, made up of a wide variety of materials which are in the form of building debris, rubble, earth, concrete, steel, timber, and mixed site clearance materials, arising from various construction activities including land excavation or formation, civil and building construction site, clearance, demolition activities, road-work, and building renovation.

On the other hand, Koskela [7] defined waste as any inefficiency that results in the use of equipment, materials labor, or capital in larger quantities than those considered as necessary in the production of a building. More recent study by Koshy and Apte [8] defined waste as any losses produced by activities that generate direct or indirect costs but do not add any value to the product from the point of view of the client.

\section{Identification and Causes of Material Wastage}

4.1. Identification of Material Wastage. There are many ways through which causes of wastage can be identified. Chandler [9] identified two areas of responsibility where action can be exercised to control material wastage, namely, in the design stage and management on site. Formoso et al. [10] stated that waste can be categorized according to its source, namely, the stage in which the root causes of waste occur. Waste may result from process preceding construction, such as material manufacturing, design, material supply, and planning as well as the construction stage.

E. Skoyle and J. Skoyle [11] divided wastage into two types. The first is direct waste which is the loss of these materials, which were damaged and subsequently used or which were lost during the building process. The second is indirect waste which was distinguished from direct waste because it is a monetary loss and the materials were not lost physically.

4.2. Causes of Material Wastage. Bossink and Brouwers [12] classified the main waste causes in construction into six sources, which are design, procurement, material handling, operation, residual, and others. Also Gavilan and Bernold [13] used the same six categories.

Waste production on construction sites is often due to inadequate storage and protection, poor or multiple handling, poor site control, overordering of material, bad stock control, lack of training, and damage to material during delivery [14]. Other researchers categorized these causes into four categories, according to Lingard et al. [15], procurement, handling, operation, and culture, while Ekanayake and Ofori [16] grouped factors generating material waste into design, procurement, handling of material, and operation.

Muhwezi et al. [17] classified materials wastage on building construction projects into 9 groups. These are design and documentations, site management and practices, procurement, materials handling, storage, transportation, operation, and environmental and other conditions.

\section{Research Plan and Methodology}

For the purpose of achieving objectives, a questionnaire was adopted as the major source of data. Designing and preparing the form used was based on the theoretical study of the subject matter including the resources, periodicals, and literatures in addition to face-to-face interviews with engineers representing the main parties involved in the construction process.

5.1. The Questionnaire Design. During the theoretical study, more than 100 causes of wastage were collected and distributed on six categories. Prior to the final formulation of the form, a pilot survey was conducted. The main purpose was to eliminate the less important questions and to check the clarity and feasibility assurance. The pilot study was carried out through 10 engineers with experience of more than 20 years.

The form was revised in accordance with the feedback received. The final number of causes adopted was 60 causes distributed on the six major groups (10 causes for each group). These are as follows.

Group 1: design and contract documents;

Group 2: site management;

Group 3: procurements;

Group 4: storage and handling of materials;

Group 5: workers and supervision;

Group 6: site conditions and external factors.

Also the form included the perception of the respondents about the estimated percentage for each type of materials selected. The respondents were requested, depending on their previous experience in implementing construction projects, to score their opinions on percentage of construction materials wastage as follows: $0-10 \%, 11-20 \%, 21-30 \%, 31-40 \%$, and $41-50 \%$. The wastage percentage would cover all stages from design through purchasing, transportation, storage, and putting in place. The kinds of materials selected are concrete, steel reinforcements, concrete blocks, cement, sand, ceramic tiles, aggregates, facing stones, timber for formworks, and PVC water pipes.

5.2. Distribution of Questionnaire. The forms were distributed to a wide range of engineering staff representing parties involved in the construction process (clients, consultants, and contractors). Number of sets distributed and received is shown in Table 1. 
TABLE 1: Number of questionnaire sets.

\begin{tabular}{lcccc}
\hline & Clients & Consultants & Contractors & Total \\
\hline Number distributed & 80 & 80 & 80 & 240 \\
Number received & 53 & 57 & 50 & 160 \\
Response rate & $66 \%$ & $71 \%$ & $63 \%$ & $67 \%$ \\
\hline
\end{tabular}

For the analysis of results, 50 forms for each class of respondents were selected to simplify the analysis. The selection was made randomly.

5.3. Method of Data Analysis. Descriptive and frequency statistical analysis techniques were used to analyze the data collected in the survey. However, an advanced and accurate method is necessary to analyze the data in a systematic, fast, and reliable way. For this purpose, the computer software Statistical Package for Social Science (SPSS 16) and MS Excel were selected.

The data collected from the survey were analyzed using the frequency and severity index method [18]. Details of both frequency and severity index analysis are explained below.

According to Assaf and Al-Hejji [18], a formula as shown in (1) was used to rank wastage based on frequency of occurrence as identified by the participants, which is called the Frequency Index (F.I). Consider

$$
\text { Frequency Index }(\text { F.I })(\%)=\frac{\sum a(n / N)}{5} \times 100,
$$

where $(a)$ is the constant expressing weighting given to each response (ranges from 1 for never up to 5 for very high occurrence), $n$ is the frequency of the responses, and $N$ is the total number of responses.

Similarly, a formula as shown in (2) is used to rank wastage based on severity index as indicated by the participants, which is called Severity Index (S.I). Consider

$$
\text { Severity Index }(\text { S.I })(\%)=\frac{\sum a(n / N)}{5} \times 100,
$$

where $(a)$ is the constant expressing weighting given to each response (ranges from 1 for no effect to 5 for very severe effect), $n$ is the frequency of the response, and $N$ is the total number of responses.

Importance Index. The importance index of each cause is calculated as a function of both frequency and severity indices, as follows:

$$
\text { Importance Index }(\mathrm{I} . \mathrm{I})(\%)=\frac{\text { F.I }(\%) \times \text { S.I }(\%)}{100} .
$$

\section{Presentation of the Results}

6.1. Causes of Wastage. The ranking of participant's responses to the most important 25 causes is shown in Table 2.

6.2. Percentage of Wastage. Table 3 reveals quantitative assessment of wastage to the ten selected types of materials due to cutting, transit, theft and vandalism, and application.
The table indicates that sand had highest percentage of waste of about $21 \%$ followed by aggregates with wastage of about $20.7 \%$; PVC water pipes have $19.6 \%$ and similar results for timber formworks. On the other hand, facing stones have the least percentage wastage of $15.14 \%$.

\section{Discussions of the Results}

7.1. Causes of Wastage of Material. The questionnaire of this study considered 60 factors which cause waste of materials in construction projects in Jordan. The results shown in Table 2 indicate the frequent design and client's changes; rework due to workers mistakes; poor contract documents; wrong and lack of storage of materials; poor strategy of waste minimization; shortage and lack of experience of skilled workers; poor site conditions; damage during transportation; theft and vandalism; and mistakes in quantity surveying and overallowance were ranked in the first ten positions as the most significant waste causes on sites.

Table 3 shows that "Change to the design" is ranked first with Importance Index of 55.54. These changes while construction is in progress can result in waste in different ways. Firstly if the construction materials have already been purchased based on the original design, waste will result if the materials cannot be resold or returned to the supplier. Similarly if a structure has already been constructed, a change in design may result in partial demolition, thus resulting in material wastage. In their study, Faniran and Caben [19] revealed that design changes were the most significant source of construction waste which was ranked the highest. Similarly Ekanayake and Ofori [16] found that design changes were ranked as the most significant factor leading to site waste.

The "Rework due to worker's mistakes" was ranked in the second position with Importance Index of 54.68. Worker's mistakes may be a result of their inefficiency, inexperience, or the contractor's bad supervision. Errors by trades labors were considered one of the main causes of material waste in operational group in Singapore construction industry; those results were found by Ekanayake and Ofori [16].

The "Poor contract documents" was ranked in third place with Importance Index of 52.40. This cause of wastage was strongly supported by contractors. This cause wastage has low effect previously by Ekanayake and Ofori [16].

The study revealed that the "Wrong and lack of storage of materials" was ranked in the fourth position with Importance Index of 50.75. This cause can result in many different ways. Enshassi [20] also found that inadequate stacking and insufficient storage of materials was one of the material waste factors in Gaza Srip. Similar studies by Faniran and Caben [19] and Poon et al. [21] concluded that inappropriate storage of material was the main cause of wastage on construction projects.

Table 2 showed that "Poor strategy for waste minimization" is ranked fifth with Importance Index of 49.17. From the author's experience and discussions with survey's respondents, contracting companies usually have a plan to manage the materials in construction projects. These plans are represented in managing material purchasing, delivery, inventories, stockiest, handling, and transportation. However 
TABLE 2: Ranking of causes of wastage.

\begin{tabular}{|c|c|c|c|c|}
\hline Cause of wastage & F.I & S.I & I.I & Rank \\
\hline Frequent design and client's changes & 74.21 & 74.84 & 55.54 & 1 \\
\hline Rework due to workers mistakes & 73.56 & 74.33 & 54.68 & 2 \\
\hline Poor contract documents & 72.63 & 72.15 & 52.40 & 3 \\
\hline Wrong and lack of storage of materials & 71.84 & 70.65 & 50.75 & 4 \\
\hline Poor strategy for waste minimization & 70.01 & 70.23 & 49.17 & 5 \\
\hline Shortage and lack of experience of skilled workers & 69.66 & 69.69 & 48.55 & 6 \\
\hline Poor site conditions & 70.01 & 68.52 & 47.97 & 7 \\
\hline Damage during transportation & 69.92 & 67.53 & 47.22 & 8 \\
\hline Theft and vandalism & 68.50 & 68.35 & 46.82 & 9 \\
\hline Mistakes in quantity surveying and overallowance & 68.11 & 67.25 & 45.80 & 10 \\
\hline Poor quality and nonavailability of equipment & 67.79 & 66.34 & 44.97 & 11 \\
\hline Weather conditions & 68.02 & 65.89 & 44.82 & 12 \\
\hline Waste resulting from poor packaging & 67.59 & 65.31 & 44.14 & 13 \\
\hline Leftover material on site & 66.15 & 66.02 & 43.67 & 14 \\
\hline Wrong handling of materials & 65.13 & 65.42 & 42.61 & 15 \\
\hline Poor quality of materials & 64.25 & 65.12 & 41.84 & 16 \\
\hline Ordering errors & 63.70 & 65.32 & 41.61 & 17 \\
\hline Purchasing materials not complying with specifications & 63.01 & 64.26 & 40.49 & 18 \\
\hline Supply in loose form & 61.98 & 65.06 & 40.32 & 19 \\
\hline Complicated design & 61.88 & 64.39 & 39.84 & 20 \\
\hline Damage caused by workers due to lack of experience & 60.25 & 64.23 & 38.70 & 21 \\
\hline Long project duration & 58.96 & 63.48 & 37.43 & 22 \\
\hline Unnecessary material handling & 58.46 & 62.34 & 36.44 & 23 \\
\hline Change in material prices & 57.44 & 62.18 & 35.72 & 24 \\
\hline Interaction between various specialists & 56.31 & 55.98 & 31.52 & 25 \\
\hline
\end{tabular}

TABLE 3: Results of the survey, percentages of wastage of materials.

\begin{tabular}{|c|c|c|c|c|c|c|}
\hline \multirow{2}{*}{ Material } & \multicolumn{5}{|c|}{ Percentages of wastage of materials } & \multirow{2}{*}{ Mean } \\
\hline & $0-10 \%$ & $11-20 \%$ & $21-30 \%$ & $31-40 \%$ & $41-50 \%$ & \\
\hline Sand & 35 & 44 & 36 & 22 & 13 & 20.98 \\
\hline Aggregate & 40 & 45 & 27 & 21 & 17 & 20.70 \\
\hline PVC water pipes & 48 & 38 & 29 & 22 & 13 & 19.61 \\
\hline Timber for formworks & 44 & 40 & 35 & 20 & 10 & 19.49 \\
\hline Cement & 48 & 46 & 28 & 19 & 9 & 18.34 \\
\hline Concrete block & 55 & 44 & 30 & 12 & 9 & 17.05 \\
\hline Steel reinforcement & 56 & 42 & 30 & 16 & 6 & 16.91 \\
\hline Concrete & 60 & 40 & 27 & 14 & 9 & 16.76 \\
\hline Ceramic tiles & 60 & 49 & 22 & 15 & 4 & 15.57 \\
\hline Facing stones & 68 & 35 & 30 & 15 & 2 & 15.14 \\
\hline
\end{tabular}

TABLE 4: F.I, S.I, and I.I ranking of the groups of factors.

\begin{tabular}{|c|c|c|c|c|}
\hline Group & F.I & S.I & I.I & Rank \\
\hline G1: factors related to design and contract documents & 66.74 & 66.36 & 44.29 & 1 \\
\hline G5: factors related to workers and supervision & 65.31 & 62.75 & 40.98 & 2 \\
\hline G4: factors related to storage and materials handling & 57.09 & 58.39 & 33.33 & 3 \\
\hline G3: factors related to procurement & 55.35 & 53.33 & 29.52 & 4 \\
\hline G6: factors related to site conditions and external factors & 52.69 & 50.48 & 26.60 & 5 \\
\hline G2: factors related to site management & 49.22 & 48.66 & 23.95 & 6 \\
\hline
\end{tabular}


these plans are often neglected by site managers. Jaillon et al. [22] in Hong Kong stated that lack of strategy for waste minimization was the main source of construction waste.

The "Shortage and lack of experience of skilled workers" was ranked in the sixth place with Importance Index of 48.55 . Lack of experience may result lack of trade's skills which lead to waste. Jaillon et al. [22] indicated that lack of experience of skilled labor was the main cause of building waste on sites in Hong Kong. Alwi et al. [23] revealed that lack of trade's skill was the main cause of construction waste and the contractors are still facing a lack of trade's skills to complete a project satisfactorily in Indonesian construction projects.

Table 4 gives brief result of the collected data and illustrates the frequency, severity, and importance of each group. The survey revealed that the factors in the design and contract documents (G1) group are the major causes of material waste with average I.I of 44.29 and the highest ranking, while site management group (G2) is the lowest ranking with I.I of 23.95.

7.2. Magnitude of Wastage of Materials. The study concluded that construction wastage materials are accounted for by values between 15 and $21 \%$ in Jordanian construction sites.

These figures seem to be high if compared with results obtained from construction sites in developed countries like USA and UK. The figures in these two countries are accounted to be 3.5 to $10 \%$ [24]. Another study by Poon et al. [21] about wastage of materials for private residential buildings in Hong Kong showed slightly lower figures than those in Jordan.

There are many other research works studied about the reasons for wastage of each type of the abovementioned materials [25-27].

\section{Recommendations}

(a) Improving the standard of the contract documents to avoid wastage resulting from poor documents, design changes, and changes of the client's requirements and avoiding design errors should be done.

(b) The contractors should play important role in reducing the waste during the construction process. This would be through implementing good strategies for resource management, waste minimization, procurement policy, control of the progress of the project, and coordination and communications between parties.

(c) Preparing better storage facilities near the site and avoiding unnecessary material handling are recommended.

(d) Employing qualified on-site administrative staff by the contractors to avoid mistakes in quantity surveying and overallowances, ordering mistakes, and poor coordination between warehouse and construction should be done.

(e) Employing skilled experienced labor and supervisors and implementing training programs for the jobs should be done. (f) Introduce a good security system including fencing, lighting, and secured storage to avoid theft and vandalism.

(g) $15-21 \%$ allowance for construction materials wastage in Jordan is recommended.

\section{Conflict of Interests}

The author declares that there is no conflict of interests regarding the publication of this paper.

\section{References}

[1] Jordan Real Estate Sector, “Thriving on growth," Global Investment House, 2012.

[2] Ministry of Housing and Reconstruction, "Waste on Jordanian construction sites," 2013.

[3] L. L. Ekanayake and G. Ofori, "Building waste assessment score: design-based tool," Building and Environment, vol. 39, no. 7, pp. 851-861, 2004.

[4] L. Y. Shen and V. W. Y. Tam, "Implementation of environmental management in the Hong Kong construction industry," International Journal of Project Management, vol. 20, no. 7, pp. 535-543, 2002.

[5] Keal, "Reduction material wastage in construction," 2007, http://www.wrap.org.UK/construction.

[6] A. Dania, J. Kehinde, and K. Bala, "A study of construction material waste management practices by construction firms in Nijeria," in Proceedings of the 3rd Scottish Conference for Postgraduate Researchers of the Built and Natural Environment, Building Research Report Series, pp. 121-129, Caledonia University, Scotland, UK, 2007.

[7] L. Koskela, "Application of the new production philosophy to construction," CIFE Technical Report \# 72, Stanford University, Stanford, Calif, USA, 1992.

[8] R. Koshy and E. M. Apte, "Waste minimization of construction materials on bridge site (cement and reinforcement steel )a regression and correlation analysis," International Journal of Engineering and Innovative Technology, vol. 2, no. 1, pp. 6-14, 2012.

[9] I. E. Chandler, Construction Management in Principle and Practice, McGraw Hill, London, UK, 1978.

[10] C. T. Formoso, E. L. Isatto, and E. H. Hirota, "Method of waste control in the building industry," in Proceedings of the 7th Conference of the International Group for Lean Construction (IGLC-7), University of California, Berkley, Calif, USA, 1999.

[11] E. Skoyle and J. Skoyle, Waste Prevention on Site, Mitchell, London, UK, 1987.

[12] B. A. G. Bossink and H. J. H. Brouwers, "Construction waste: quantification and source evaluation," Journal of Construction Engineering and Management, vol. 122, no. 1, pp. 55-60, 1996.

[13] R. M. Gavilan and L. E. Bernold, "Source evaluation of solid waste in building construction," Journal of Construction Engineering and Management, vol. 120, no. 3, pp. 536-552, 1994.

[14] J. Swinburne, C. E. Udeaja, and N. Tait, "Measuring material wastage on construction sites: a case study of local authority highway projects," Built and Natural Environment Research Papers, vol. 3, no. 1, pp. 31-41, 2010.

[15] H. Lingard, P. Graham, and G. Smithers, "Employee perceptions of the solid waste management system operating in a large 
Australian contracting organization: implications for company policy implementation," Construction Management and Economics, vol. 18, no. 4, pp. 383-393, 2000.

[16] L. L. Ekanayake and G. Ofori, "Construction material waste source evaluation," in Proceedings of the 2nd South African on Sustainable Development in the Built Environment, Pretoria, South Africa, 2000.

[17] L. Muhwezi, L. Chamuriho, and N. Lema, "An investigation into materials wastes on building construction projects in KampalaUganda," Scholarly Journal of Engineering Research, vol. 1, no. 1, pp. 11-18, 2012.

[18] S. A. Assaf and S. Al-Hejji, "Causes of delay in large construction projects," International Journal of Project Management, vol. 24, no. 4, pp. 349-357, 2006.

[19] O. Faniran and G. Caben, "Minimizing waste on construction project sites," Engineering, Construction and Architectural Management, vol. 5, no. 2, pp. 182-188, 1998.

[20] A. Enshassi, "Materials control and waste on building sites," Building Research and Information, vol. 24, no. 1, pp. 31-34, 1996.

[21] C. S. Poon, A. T. W. Yu, S. W. Wong, and E. Cheung, "Management of construction waste in public housing projects in HongKong," Construction Management and Economics, vol. 22, no. 7, pp. 675-689, 2004.

[22] L. Jaillon, C. S. Poon, and Y. H. Chiang, "Quantifying the waste reduction potential of using prefabrication in building construction in Hong Kong," Waste Management, vol. 29, no. 1, pp. 309-320, 2009.

[23] S. Alwi, K. Hampson, and S. Mohamed, "Non value-adding activities, a comparative study of Indonesian and Australian construction projects," in Proceedings of the 10th Annual Conference of the International Group of Lean Construction (IGLC '02), Gramado, Brazil, 2002.

[24] Z. Chen, H. Li, and C. T. C. Wong, "An application of barcode system for reducing construction wastes," Automation in Construction, vol. 11, no. 5, pp. 521-533, 2002.

[25] W. Lu, H. Yuan, J. Li, J. J. L. Hao, X. Mi, and Z. Ding, "An empirical investigation of construction and demolition waste generation rates in Shenzhen city, South China," Waste Management, vol. 31, no. 4, pp. 680-687, 2011.

[26] M. Baytan, Origins and magnitude of waste in the Turkish construction industry [M.S. thesis], Middle East Technical University, Ankara, Turkey, 2007.

[27] L. Y. Shen, W. Y. Tam, C. W. Chan, and S. Y. Kong, "An examination on the waste management practice in the local construction sites," Hong Kong Surveyor, vol. 12, no. 1, pp. 3948, 2002. 

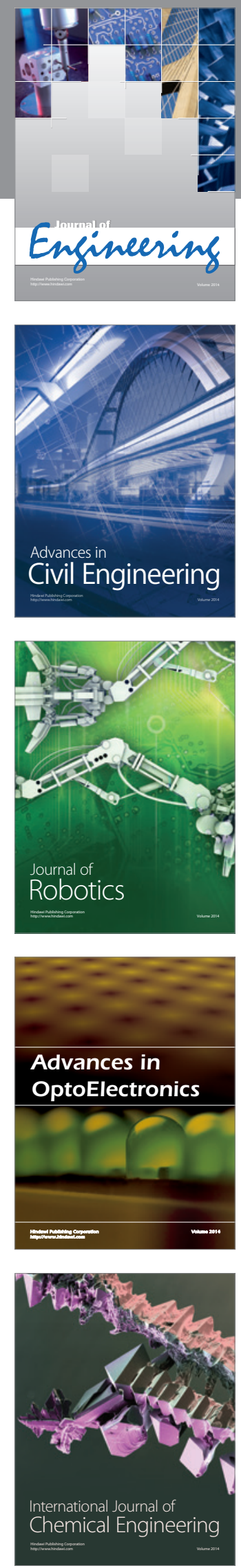

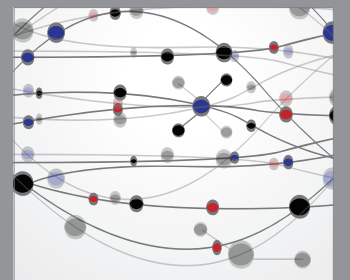

The Scientific World Journal
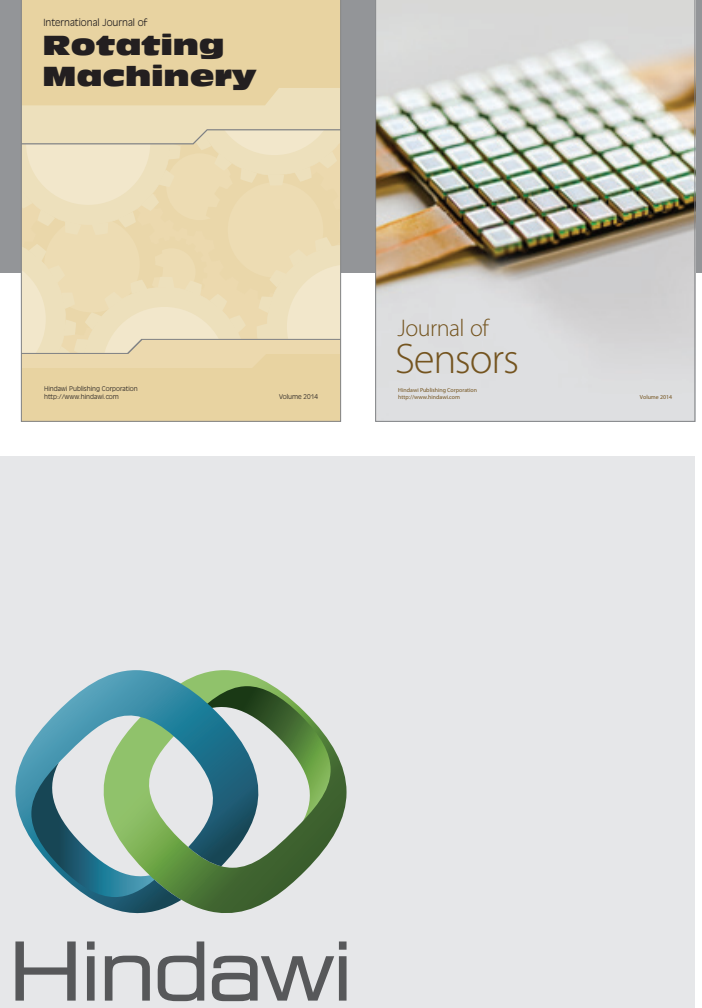

Submit your manuscripts at http://www.hindawi.com
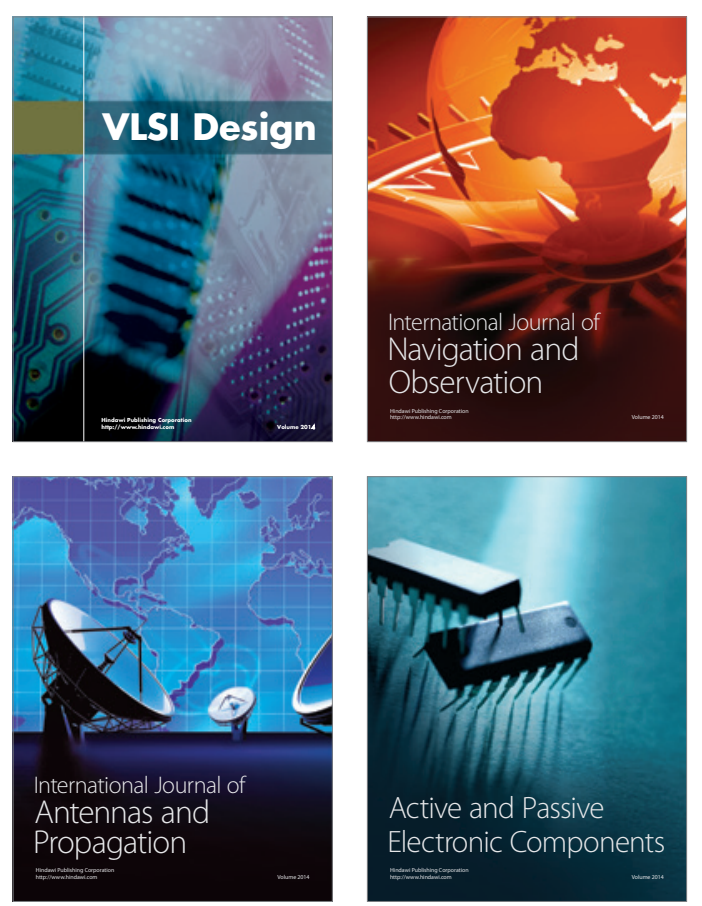
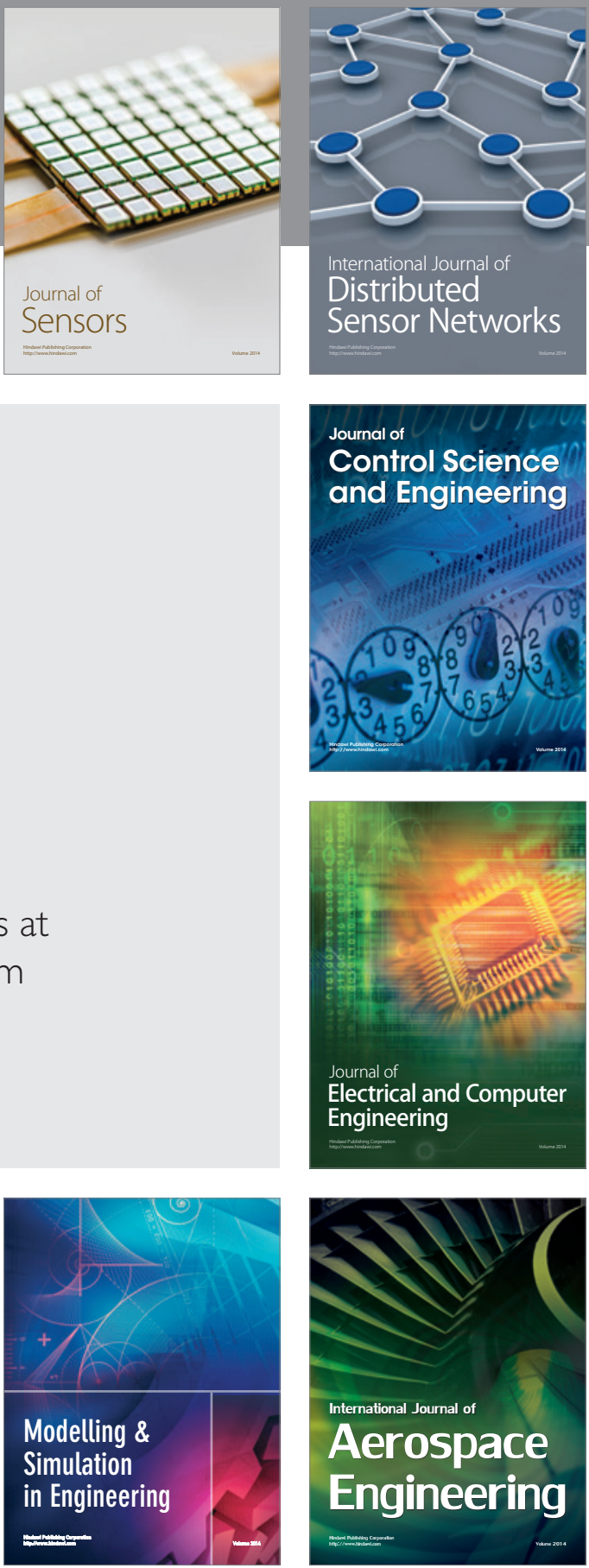

Journal of

Control Science

and Engineering
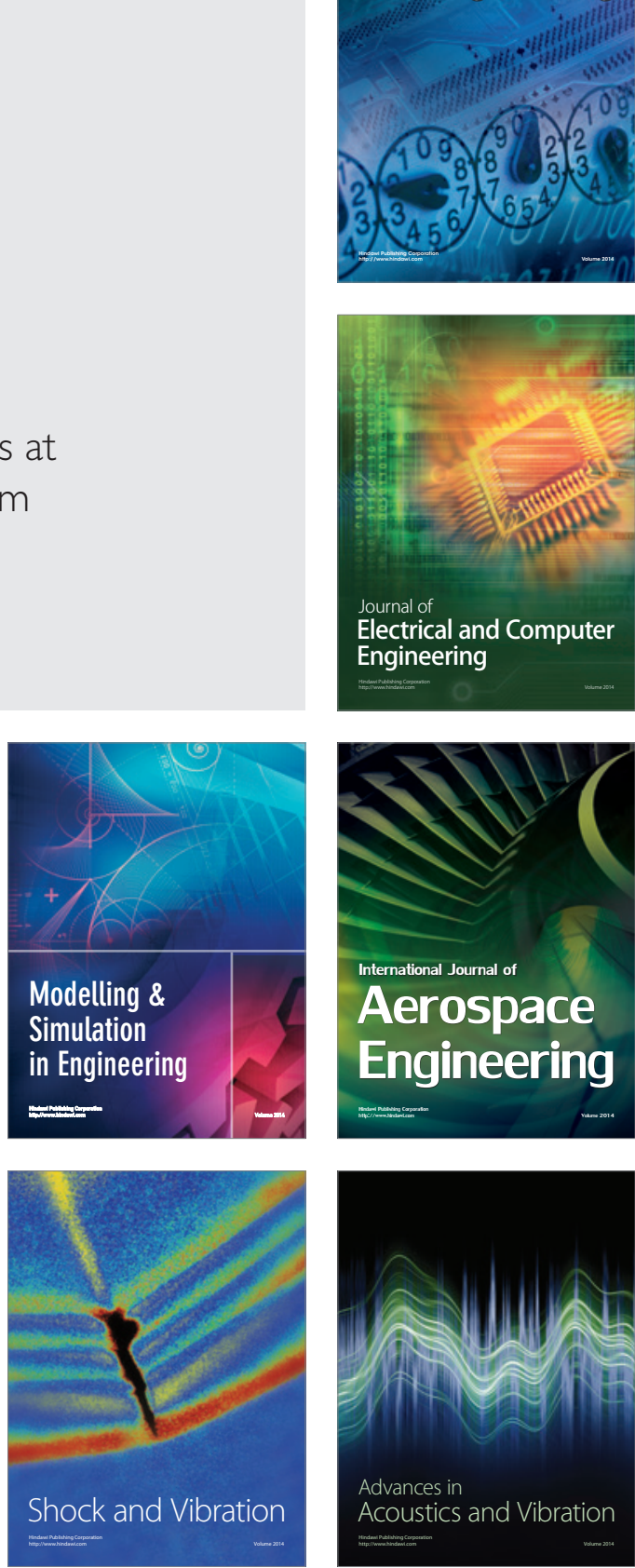